Egyptian Journal of Aquatic Biology \& Fisheries

Zoology Department, Faculty of Science,

Ain Shams University, Cairo, Egypt.

ISSN $1110-6131$

Vol. 24(2): 209 - 223 (2020)

www.ejabf.journals.ekb.eg

\title{
Assessment of metallothionein expression in Biomphalaria alexandrina snails and Oreochromis niloticus Fish as a biomarker for water pollution with heavy metals.
}

\author{
Hanaa M. M. El-Khayat ${ }^{1}$ Hoda M. Abu Taleb ${ }^{1}$, Noha S. Helal ${ }^{2}$, Samah I. Ghoname ${ }^{1, *}$
}

1- Depart. of Env. Research and Medical Malacology, Theodor Bilharz Research Institute, Egypt.

2- Depart. of Pathology Theodor Bilharz Research Institute, Giza .Egypt. P.O Box 30

*Corresponding Author: samah.ghoname@gmail.com

\section{ARTICLE INFO}

Article History:

Received: March 1, 2020

Accepted: March28, 2020

Online: April 1, 2020

Keywords:

Metallothionein, Biomphalaria alexandrina Oreochromis niloticus immunohistochemistry, Heavy metals, Lake Manzala

\section{ABSTRACT}

Metallothioneins (MTs) are small cysteine-rich proteins that play important roles in metal homeostasis and protection against heavy metals; therefore, they were used as biomarkers to evaluate metals pollution in the aquatic ecosystem. The present work aims to evaluate the tissue immunohistochemical expression of MT in Biomphalaria alexandrina snails and Oreochromis niloticus fish collected from Lake Manzala in the area of Port-Said, Dakahlia and Damietta governorates in response to the recorded levels of $\mathrm{Cd}, \mathrm{Cu}$, and $\mathrm{Pb}$ in their aquatic habitats. The levels of the heavy metals; $\mathrm{Cd}, \mathrm{Cu} \& \mathrm{~Pb}$ in water samples from Port Said were significantly exceeded those of Dakahlia $(\mathrm{p}<0.01)$, also, a similar pattern was recorded for $\mathrm{Cu}$ levels between Damietta and Dakahlia $(p<0.01)$. Accordingly, the tissue expression of MT was significantly increased in snails and fish specimens from Port Said and Damietta compared to Dakahlia governorate specimens $(\mathrm{p}<0.01$ and $\mathrm{p}<0.05$ respectively). In general; MT immunopositivity in snails regarding the number of MT-positive cases and the number of positive cells, was observed as digestive gland > prostate tubules> ovotestis> head-foot area and in fish, it was as follows: liver \& spleen> gills > ovary. Conclusion: There is a positive correlation between heavy metals levels and MT expression in snails and fish collected from Port Said, Damietta and Dakahlia, El-Manzala Lake $(p<0.001 \& r=0.636, p<0.001 \& r=0.375$ and $p<$ $0.05 \& \mathrm{r}=0.296$, respectively), hence MT could be considered as a good potential biomarker for toxicological studies and for assessment of heavy metal stress in aquatic environment.

\section{INTRODUCTION}

Heavy metals are natural elements present in the environment (Wegwu et al., 2010). They are usually present in trace amounts in natural waters but many of them are toxic even at very low concentrations (Herawati et al., 2000). The accumulation of metals in an aquatic environment has a direct impact on the sustainability of the ecosystem. The bioavailability of any particular metal in the aquatic organisms or fish that are being 
exposed to the polluted water are faced with various threats such as neurological damage, decreased immunity, disruption in metabolic function, defect in reproduction and offspring (M'kandawire et al., 2012).

Metallothionein (MT) is a metal-binding protein which can be found in many organisms (Roesijadi, 1996). MT has been documented to bind a wide range of metals including cadmium $(\mathrm{Cd})$ (Freisinger andVašák, 2013), lead $(\mathrm{Pb})$ (Wong et al., 2017), mercury (Sutton and Tchounwou, 2007), copper ( Stern, 2010) and arsenic (Tchounwou et al., 2004). The biological functions of MTs include homeostasis of many cellular processes, regulating the metal ions for cell function and in immunoregulation in the protection against heavy metals, oxidant damages, and inflammation. Li et al. (2007) explained that MTs bind to metal ions to dispel them out of the system and prevent cellular toxicity. Theoretically, when an organism is treated or exposed to heavy metals, the synthesis of MT will increase. Thus, a polluted area with high levels of heavy metals would induce an increase in MTs in the exposed organisms, hence they were used as a biomarker to detect heavy metal pollution and the bioavailability of any particular metal in the environment (Atli and Canli, 2007). However, the regulation of metal ions by aquatic organisms is up to a certain concentration to protect themselves from adverse effects; and continuous exposure of heavy metals into the aquatic body disturbs the regulatory processes and initiates metal accumulation (El-Khayat et al., 2015). Many studies proved that the polluted water caused a severe damage to the cells and different tissues of the fish inhabiting these places (Mohamed, 2009). Metals tend to accumulate in water and move up through the food chain; therefore, studies to quantify the levels of heavy metals in environment and determine potentially hazardous levels for human are necessary (Haram, 2015).

In many species of Gastropoda (snails and slugs), $\mathrm{Cd}$ and $\mathrm{Cu}$ metabolism and detoxification are apparently linked to the expression of metal-specific MT, Biomphalaria glabrata is known to be sensitive to metal toxicity and has been proposed as an indicator of metal pollution in tropical environments (Ravera, 1977 and Allah et al., 1997). As well fish are considered to be sensitive pollution indicator because they are directly in contact with surface water and can store and metabolize the water borne pollutants (Ladhar-Chaabouni et al., 2012). MT can regulate heavy metals such as Zn and $\mathrm{Cu}$ in fish and protect aquatic biota from metal toxicity and oxidative stress (Rosesijadi, 1996).

Lake Manzala is the largest of the northern deltaic lakes in Egypt that lies on the coast of Mediterranean Sea in the governorates Port Said, Damitta and Dakahlia. It is exposed especially in its southern part to high levels of pollutants from industrial, domestic and agricultural resources (Ibrahim et al., 1999). The present study aimed to assess the tissue expression of Metallothionein in Biomphalaria alexandrina snails and Oreochromis niloticus fish collected from Lake Manzala as a biomarker for heavy metal pollution in the lake.

\section{MATERIALS AND METHODS}

\section{Study area:}

This study was carried out in 12 different sites in Lake Manzala in three governorates; Port-Said (5 sites), Dakahlia (4 sites) and Damietta (3 sites), 2015 


\section{Sampling:}

Snail samples were collected by a standard dip net (Jobin, 1970 and Yousif et al., 1992) from the water banks of Lake Manzala utilizing a motorized boat. The collected snails from each of the tested sites were placed in a plastic aquarium containing water from their habitat, transported to the laboratory and examined individually for natural trematode infections by the cercarial shedding test (McClelland, 1965). The negative (uninfected) Biomphalaria snails were used only where they removed from their shells gently then fixed in $10 \%$ buffered neutral formalin solution. On the other hand, fish specimens were collected by the local fishermen from each governmental site, anesthetized, dissected to obtain gills, liver, spleen and ovary that immediately fixed in $10 \%$ neutral-buffered formalin solution then transferred to the laboratory.

Water samples were collected in sterilized one-liter polyethylene bottles from each investigated site at $30 \mathrm{~cm}$ below the water surface. Samples were transported in an ice box to the laboratory where they were acidified with concentrated nitric acid $2 \mathrm{ml} / \mathrm{l}$, filtrated through filter papers then syringe-membrane filter pore size $0.45 \mathrm{~mm}$ and kept at $4^{\circ} \mathrm{C}$ till analysis.

\section{Heavy metals analysis:}

Metals stock standards of $\mathrm{Cd}, \mathrm{Pb} \& \mathrm{Cu}$ were used in the determination of their respective heavy metals in the collected water samples using Atomic Absorption Spectrophotometry (AAS) (GBC AVANTA 3000, Australia) and expressed as ppb using Graphite furnaceAAS, in Environmental Research Laboratory, Theodor Bilharz Research Institute (TBRI).

\section{Immunohistochemical technique}

After fixation for $6 \mathrm{hrs}$ snail tissues and fish organs were washed in $70 \%$ ethyl alcohol to get rid of excess fixative and then dehydrated through ascending grades of ethyl alcohol. The specimens were cleared in xylene for 15-20 min then embedded in paraffin wax. The paraffin wax block was sectioned at $5 \mu \mathrm{m}$, then Formalin-fixed paraffin sections $(5 \mu \mathrm{m}$ in thickness) were cut undergo deparaffinization, rehydration and endogenous peroxidase was blocked with methanol containing 3\% hydrogen peroxide. Sections were incubated overnight at $4^{\circ} \mathrm{C}$ in humid chamber with the primary antibodies: metallothionein polyclonal antibody (Biospes, Catalog no. YPA1550, China) at an optimal dilution of 1:100, with application of Power stain poly HRP DAB system (Genemed, Catalog no. 540017, USA). The antigen was detected by the addition of DAB substrate chromogen solution. Finally, slides were counterstained with hematoxylin and eosin, dehydrated in alcohol and mounted. Metallothionein stained sections were assessed by using light microscope (Scope A1, Axio, Zeiss, Germany). Photomicrographs were taken using a microscope-camera (AxioCam, MRc5, Zeiss, Germany). Metallothionein positivity was indicated by brownish cytoplasmic staining of cells.

\section{Statistical analysis:}

Data were presented as mean \pm SE. Multi-group comparison was performed (KruskalWallis 1-way ANOVA for k samples. Spearman's rho Correlation and Chi square test was followed using the computer software package SPSS 24.0. Differences among individual groups were determined using the least significant difference test. $\mathrm{p}<0.05$ was considered as statistical significant. 


\section{RESULTS}

\section{Heavy Metals analysis:}

Results of $\mathrm{Cd}, \mathrm{Pb} \& \mathrm{Cu}$ in water samples collected from the Lake Manzala examined sites are presented in Table (1) in comparison with the levels of US Environmental Agency (USEPA), 2011. The Lake sites in Port Said and Damietta were highly polluted with $\mathrm{Cu}$ compared to Dakahlia, moreover the recorded mean value exceeded the permissible level by up to 8.2 times in Damietta and 4.4 times in Port Said $(\mathrm{p}<0.01)$, but in Dakahlia it was less than the level of USEPA. Cd was significantly increased in Port Said compared to Dakahlia with mean value 3.6 times over the USEPA level. Similarly, $\mathrm{Pb}$ was significantly increased in Port Said compared to Dakahlia and Damietta with mean value 1.7 times over the concern level of USEPA.

\section{Immunohistochemical expression:}

\section{Expression of metallothionein reactivity in $B$. alexandrina snails}

The sections of head-foot, prostate tubules, stomach, digestive gland and ovotestis of $B$. alexandrina snails collected from Lake Manzala in the area of Dakahlia, Port Said and Damietta governorates and control laboratory bred ones were examined for their expression of MT reactivity (Figure 1) using MT polyclonal antibody. The pattern of positive MT immunoreactivity was indicated by brownish cytoplasm of staining cells.

Table 1: Levels of Heavy Metals (ppb) in water samples collected from Lake Manzala referred to the studied Governments.

\begin{tabular}{|lcccccc|}
\hline Governments & $\begin{array}{c}\text { Cadmium } \\
\text { Mean } \pm \text { SE }\end{array}$ & $\begin{array}{c}\text { Folds } \\
\text { M/PL }\end{array}$ & $\begin{array}{c}\text { Lead } \\
\text { Mean } \pm \text { SE }\end{array}$ & $\begin{array}{c}\text { Folds } \\
\text { M/PL }\end{array}$ & $\begin{array}{c}\text { Copper } \\
\text { Mean } \pm \text { SE }\end{array}$ & $\begin{array}{c}\text { Folds } \\
\text { M/PL }\end{array}$ \\
\hline PL( ppb) & 2 & & 65 & & 13 & \\
\hline Dakahlia & $2.32 \pm 0.62$ & 1.16 & $23.99 \pm 4.62$ & 0.369 & $6.60 \pm 0.36$ & 0.50 \\
\hline Damietta & $4.35 \pm 1.52$ & 2.18 & $88.5 \pm 28.44$ & 1.36 & $106 \pm 43.83^{\text {a,b }}$ & 8.2 \\
\hline Port Said & $7.20 \pm 3.31^{* *}$ & 3.6 & $112 \pm 9.8^{*, * *}$ & 1.7 & $57.51 \pm 6.63^{* *, a}$ & 4.4 \\
\hline
\end{tabular}

${ }^{*} p<0.05$ significant increase than Damietta; ${ }^{* *} p<0.01$ significant increase than Dakahlia

${ }^{\mathrm{a}} p<0.01$ significant increase than Dakahlia; ${ }^{\mathrm{b}} p<0.01$ significant increase than Port Said and Dakahlia

PL: permissible limits according to EPA (2011).

Results (Table 2a and Fig. 1) show that tissues of control snails in head foot, prostatic tubules, stomach, digestive gland and ovotestis were negative for MT expression, while the expression of MT was recorded in snail specimens from Port Said and Damietta with high percentages compared to Dakahlia ones $(p<0.01$ and $p<0.05$, respectively. Positive MT immunostaning reactivity was seen in the unicellular glands in head-foot of Port Said (Fig. 2 a) and Damietta (Figure 2- b) specimens. MT positive expression was found in prostate tubules tissues in snail specimens from both of Port Said (Figure 3- a) and Damietta governorates (Fig. 3- b). Moreover, digestive gland showed more positive immunostaning reactivity for MT in snails from Port Said (Fig. 4 a) and Damietta (Fig. 
4b). The ovotestis of snail specimens from Port Said (Fig. 5-a) and Dakahlia (Fig. 5-b) governorates exhibited, also, positive expression of MT. In general; MT immunopositivity, regarding number of MT-positive cases and number of positive cells, was arranged as digestive glands> prostate tubules>ovotestis> head-foot of snails (Table $2 b)$.

Table 2a: Metallothionein immunohistochemical reactivity in Biomphalaria alexandrina snails collected from Lake Manzala.

\begin{tabular}{|c|c|c|c|}
\hline \multirow[t]{2}{*}{ Groups } & \multirow{2}{*}{$\begin{array}{c}\text { Governorates } \\
\text { (n) }\end{array}$} & \multicolumn{2}{|c|}{ MT Immunohistochemical Reactivity } \\
\hline & & $\begin{array}{c}\text { Positive expression } \\
\text { n }(\%)\end{array}$ & $\begin{array}{c}\text { Negative expression } \\
\text { n }(\%)\end{array}$ \\
\hline \multirow[t]{3}{*}{ Control snails } & Dakahlia (5) & 0 & $5(100 \%)$ \\
\hline & Damiettaa (5) & 0 & $5(100 \%)$ \\
\hline & Port said (5) & 0 & $5(100 \%)$ \\
\hline \multirow[t]{3}{*}{ Lake snails } & Dakahlia (15) & $3(20 \%)$ & $12(80 \%)$ \\
\hline & Damietta (30) & $15(50 \%)^{*}$ & $15(50 \%)$ \\
\hline & Port said (30) & $24(80 \%)^{3 * *}$ & $6(20 \%)$ \\
\hline
\end{tabular}

$p<0.05$ Significant difference compared to Dakahlia

${ }^{*} p<0.01$ highly Significant difference compared to Dakahlia

$n$ Number of specimens

Table 2b: Metallothionein immunohistochemical reactivity in different parts of Biomphalaria alexandrina snails.

\begin{tabular}{|c|c|c|c|c|c|c|c|c|c|}
\hline \multirow{2}{*}{$\begin{array}{l}\text { Governorates } \\
\text { Lake snails }\end{array}$} & \multirow{2}{*}{$\begin{array}{l}\text { no. of } \\
\text { positive } \\
\text { cases }\end{array}$} & \multicolumn{8}{|c|}{$\begin{array}{c}\text { Mean(\%) of positive cells } \\
\pm \text { Standard Error }\end{array}$} \\
\hline & & No. & Head-Foot & No. & $\begin{array}{c}\text { Digestive } \\
\text { glands }\end{array}$ & No. & $\begin{array}{c}\text { Prostatic } \\
\text { tubules }\end{array}$ & No. & Ovotestis \\
\hline Dakahlia & 3 & - & - & 2 & $10 \pm 0$ & - & - & 1 & $20 \pm 0$ \\
\hline Damietta & 15 & 2 & $11.3 \pm 3.97$ & 7 & $38.57 \pm 2.60$ & 4 & $25.00 \pm 6.45$ & 2 & $12.5 \pm 2.5$ \\
\hline Port said & 24 & 2 & $12 \pm 1.94$ & 10 & $46.00 \pm 3.05$ & 7 & $27.14 \pm 2.85$ & 5 & $17.5 \pm 3.36$ \\
\hline
\end{tabular}

\section{Expression of metallothionein reactivity in fish organs}

Metallothionein expression liver, spleen, gills and ovary of fish control specimens were negative (Table 3a). In the fish specimens collected from different governorates (Figure 1), positive MT expression $62.5 \%$ was seen in liver tissues of fish from both of Port Said and Damietta compared to $31 \%$ positivity in Dakahlia specimens. Similar pattern was recorded in spleen and gills of specimens from Port Said and Damietta compared to Dakahlia ones. Meanwhile, in ovary tissues, $50 \%$ of fish from Damietta and Dakahlia were positive for MT compared to $25 \%$ of fish from Port Said (Table 3a). The positive immunostaning expression was observed in liver and pancreatic acini in fish specimens 
from both Damietta (Figure 6-d) and in Port-Said (Figure 6-e,f). In spleen tissues, a high MT expression was found in scattered cells of specimens from Damietta (Figure 7-b), Dakahlia (Figure 7-c) and Port Said (Figure 7-d). In fish gills, the positive MT expression was seen in scattered cells of gill fish tissues of Damietta specimens (Figure 8-b). A marked up-regulation of MT was found in filaments of pillar system in of gills tissues from Dakahlia (Figure 8-c), and Port-Said specimens (Figure 8-d). The positive MT immunostaining was found in ovarian membrane and cytoplasm of premature ova in Dakahlia specimens (Figure 9-b). Generally, the data showed a high MTs expression in sections of fish from liver, spleen and pancreatic acini in O. niloticusfish from Damitta and Port Said. According to positive number of cases and positive percentage of positive cells; MT positivity was higher in spleen \& liver than that of gills, while the least positivity of MT was seen in ovary tissues (Table 3b).

Using Sperman's rho Correlation proved a positive correlation between heavy metals $(\mathrm{Cd}$, $\mathrm{Cu}$ and $\mathrm{Pb}$ ) in polluted water and MT expression in $B$. alexandrina snails and $O$. niloticus fish from Port-Said and Damietta governorates compared to those from Dakahlia $(\mathrm{p}<0.001 \& \mathrm{r}=0.636, \mathrm{p}<0.001 \& \mathrm{r}=0.375$ and $\mathrm{p}<0.05 \& \mathrm{r}=0.296$, respectively).

Table 3a: Metallothionein immunohistochemical reactivity in studied Oreochromis niloticus fish collected from Lake Manzala.

\begin{tabular}{|c|c|c|c|c|c|c|c|c|c|c|c|c|}
\hline \multirow{3}{*}{$\begin{array}{c}\text { Organs } \\
\text { Governorates }\end{array}$} & \multicolumn{10}{|c|}{ Metallothionein Immunohistochemical Reactivity } & \multicolumn{2}{|c|}{ Total (64) } \\
\hline & \multicolumn{2}{|c|}{ Liver } & \multicolumn{2}{|c|}{ Spleen } & \multicolumn{2}{|c|}{ Gills } & \multicolumn{2}{|c|}{ Ovary } & \multicolumn{2}{|c|}{ Control } & & \\
\hline & $\begin{array}{c}\text { Positive } \\
\mathrm{n}(\%)\end{array}$ & $\begin{array}{c}\text { Negative } \\
\mathrm{n}(\%)\end{array}$ & $\begin{array}{c}\text { Positive } \\
\text { n (\%) }\end{array}$ & $\begin{array}{c}\text { Negative } \\
\text { n }(\%)\end{array}$ & $\begin{array}{c}\text { Positive } \\
\text { n (\%) }\end{array}$ & $\begin{array}{c}\text { Negative } \\
\mathrm{n}(\%)\end{array}$ & $\begin{array}{c}\text { Positive } \\
\text { n (\%) }\end{array}$ & $\begin{array}{c}\text { Negative } \\
\mathrm{n}(\%)\end{array}$ & $\begin{array}{c}\text { Positive } \\
\text { n (\%) }\end{array}$ & $\begin{array}{c}\text { Negative } \\
\text { n }(\%)\end{array}$ & $\begin{array}{c}\text { Positive } \\
(\%)\end{array}$ & $\begin{array}{c}\text { Negative } \\
(\%)\end{array}$ \\
\hline Dakahlia (16) & $\begin{array}{c}5 \\
(31 \%)\end{array}$ & $\begin{array}{c}11 \\
(69 \%)\end{array}$ & $\begin{array}{c}8 \\
(50 \%)\end{array}$ & $\begin{array}{c}8 \\
(50 \%)\end{array}$ & $\begin{array}{c}4 \\
(25 \%)\end{array}$ & $\begin{array}{c}12 \\
(75 \%)\end{array}$ & $\begin{array}{c}8 \\
(50 \%)\end{array}$ & $\begin{array}{c}8 \\
(50 \%)\end{array}$ & 0 & $\begin{array}{c}5 \\
(100 \%)\end{array}$ & $\begin{array}{c}25 \\
(39 \%)\end{array}$ & $\begin{array}{c}39 \\
(61 \%) \\
\end{array}$ \\
\hline Damietta (16) & $\begin{array}{c}10 \\
(62.5 \%)^{*}\end{array}$ & $\begin{array}{c}6 \\
(37.5 \%)\end{array}$ & $\begin{array}{c}12 \\
(75 \%)^{*}\end{array}$ & $\begin{array}{c}4 \\
(25 \%)\end{array}$ & $\begin{array}{c}9 \\
(56.3 \%)\end{array}$ & $\begin{array}{c}7 \\
(43.7 \%)\end{array}$ & $\begin{array}{c}8 \\
(50 \%)\end{array}$ & $\begin{array}{c}8 \\
(50 \%)\end{array}$ & 0 & $\begin{array}{c}5 \\
(100 \%)\end{array}$ & $\begin{array}{c}39 \\
(61 \%)\end{array}$ & $\begin{array}{c}25 \\
(39 \%)\end{array}$ \\
\hline Port Said (16) & $\begin{array}{c}10 \\
(62.5 \%) *\end{array}$ & $\begin{array}{c}6 \\
(37.5 \%)\end{array}$ & $\begin{array}{c}13 \\
(81 \%)^{*}\end{array}$ & $\begin{array}{c}3 \\
(19 \%)\end{array}$ & $\begin{array}{c}12 \\
(75 \%)^{*}\end{array}$ & $\begin{array}{c}4 \\
(25 \%)\end{array}$ & $\begin{array}{c}4 \\
(25 \%)\end{array}$ & $\begin{array}{c}12 \\
(75 \%)\end{array}$ & 0 & $\begin{array}{c}5 \\
(100 \%)\end{array}$ & $\begin{array}{c}39 \\
(61 \%)\end{array}$ & $\begin{array}{c}25 \\
(39 \%)\end{array}$ \\
\hline
\end{tabular}

${ }^{*} p<0.05$ Significant difference compared to Dakahlia

Table3b: Metallothionein immunohistochemical reactivity (Percentage of positive cells) in Oreochromis niloticus fish organs.

Mean $(\%)$ of positive cells \pm Standard Error

\begin{tabular}{|lcccccccc|}
\hline Organs & \multicolumn{2}{l}{ Liver } & \multicolumn{2}{l}{ Spleen } & \multicolumn{2}{l}{ Gills } & \multicolumn{2}{l|}{ Ovary } \\
\hline Governorates & No. & Mean \pm SE & No. & Mean \pm SE & No. & Mean \pm SE & No. & Mean \pm SE \\
\hline Dakahlia (16) & 5 & $92.5 \pm 4.27$ & 8 & $70.00 \pm 6.55$ & 4 & $35 \pm 2.88$ & 8 & $6.25 \pm 0.82$ \\
\hline Damietta (16) & 10 & $72.00 \pm 7.82$ & 12 & $86.67 \pm 1.42$ & 9 & $34 . .44 \pm 2.27$ & 8 & $6.87 \pm 0.92$ \\
\hline Port Said (16) & 10 & $73.00 \pm 7.0$ & 13 & $90 \pm 0.00$ & 12 & $47.5 \pm 3.05$ & 4 & $7.5 \pm 1.45$ \\
\hline
\end{tabular}



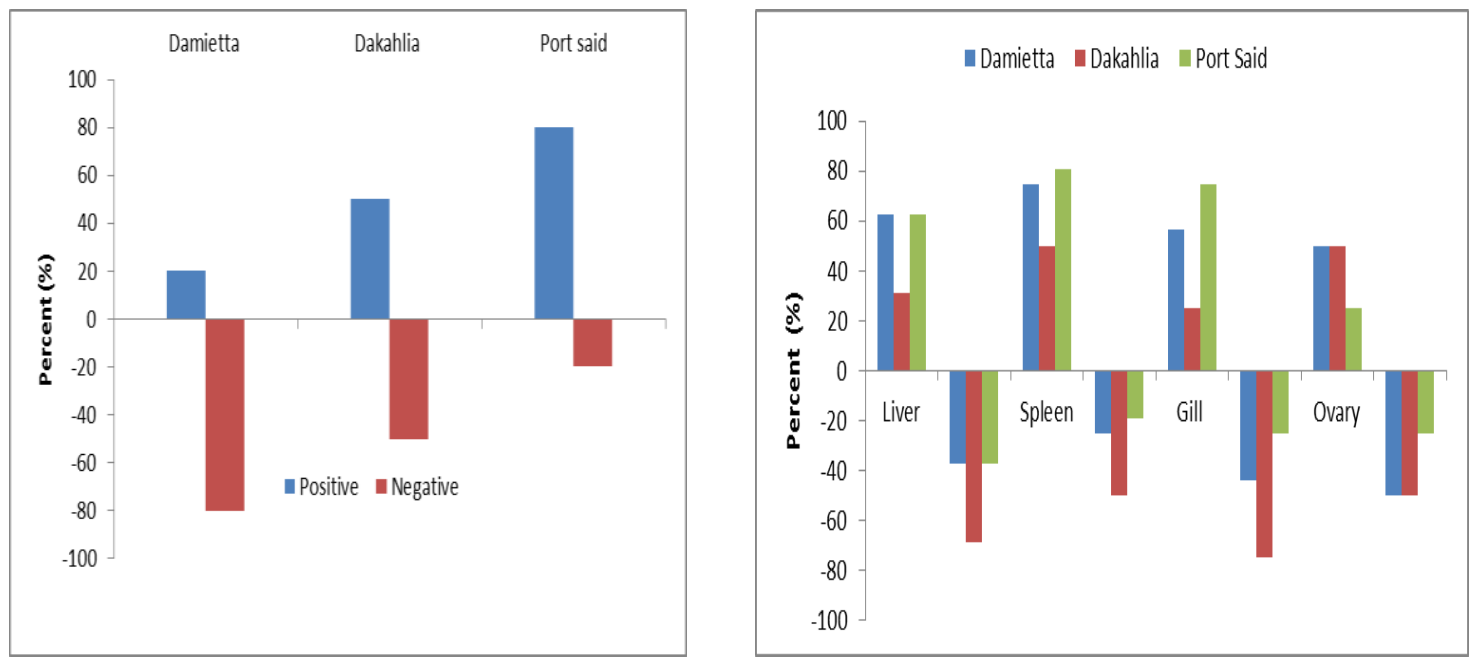

Fig.(1): Metallothionein immune histochemical reactivity in snails and fish samples collected from Lake Manzala.

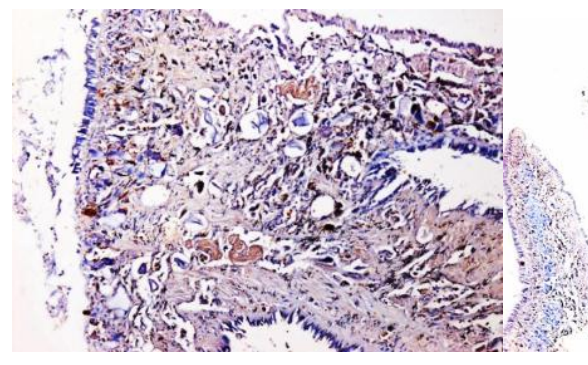

a

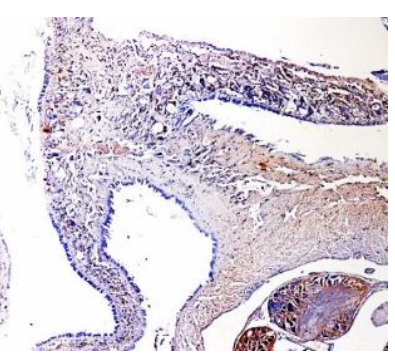

b

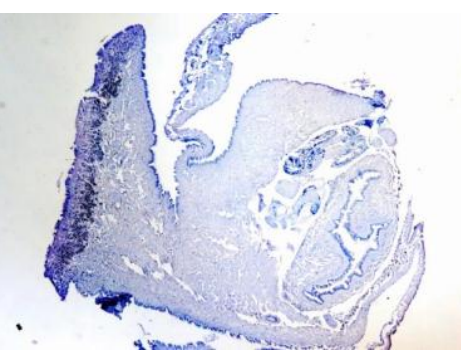

C

Fig (2) . Light photomicrograph for transverse sections in the head foot area of Biomphalaria alexandrina snails from Manzala Lake.

a) MT positivity in the unicellular glands of head food area in Port Said (MT x200)

b) MT positivity of head food area in Damietta (MT x100).

c) Negative stain for MT in head foot area in Dakahlia(MT x50).

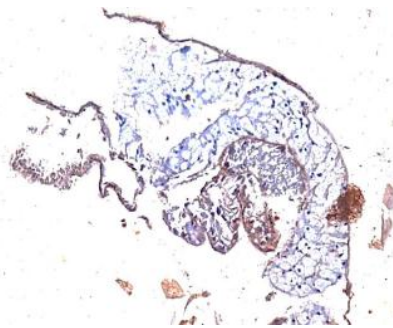

a

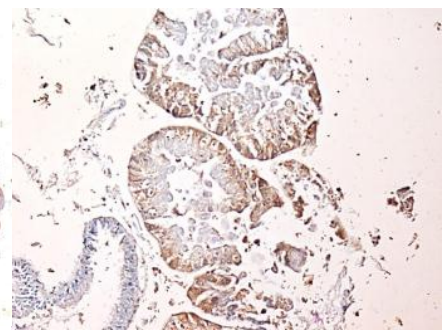

b

Fig (3). Light photomicrograph for transverse sections in the prostate tubule area of Biomphalaria alexandrina snails from Manzala Lake.

a) Positive expresssion in prostate tubules from Port Said (MT X200).

b) MT positive expresssion in prostate tubules from Damietta (MT X200) 

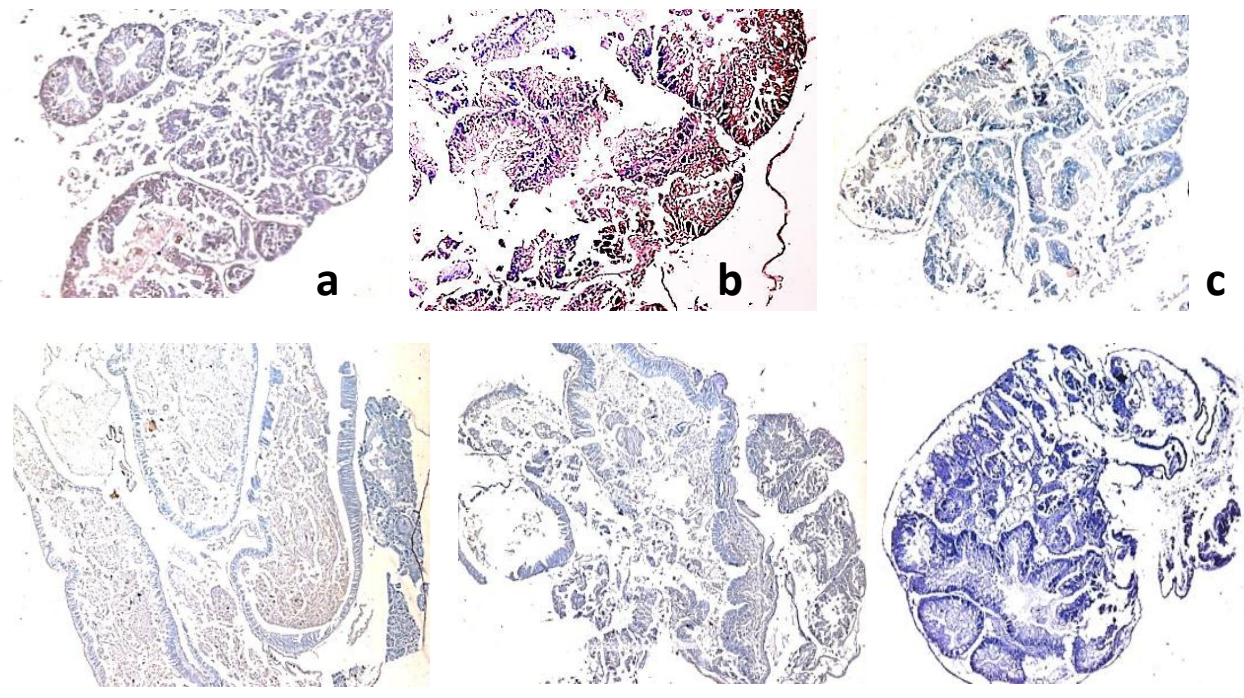

d

e

f

Fig (4). Light photomicrograph for transverse sections in the digestive gland and stomach in Biomphalaria alexandrina snails from Manzala Lake.

a) MT positivity in the digestive gland from Port Said (MT x200)

b) MT positive in the digestive gland from Damietta (MT x200)

c) MT negative in the digestive gland from Damietta (MT x200)

d) MT negative expression in the stomach from Damietta(MTX100)

e) MT negative expression in the stomach from Dakahlia (MTX100)

f) MT negative In the digestive gland from Dakahlia (MT x 100)

a

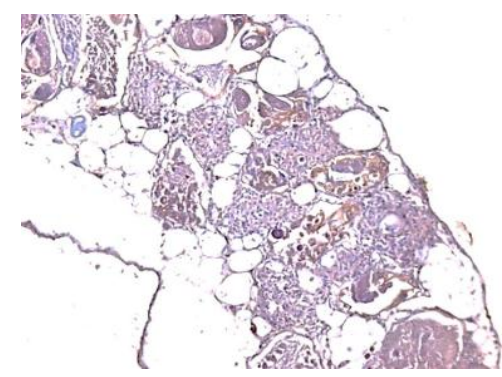

b

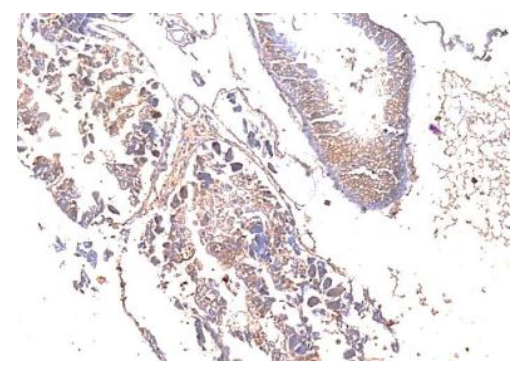

Fig (5) . Light photomicrograph for transverse sections in the ovotestis in Biomphalaria alexandrina snails from Manzala Lake.

a) MT positivity in the ovotestis from Port Said (MT x200)

b) MT positivity in the ovotestis from Dakahlia (MT x200) 


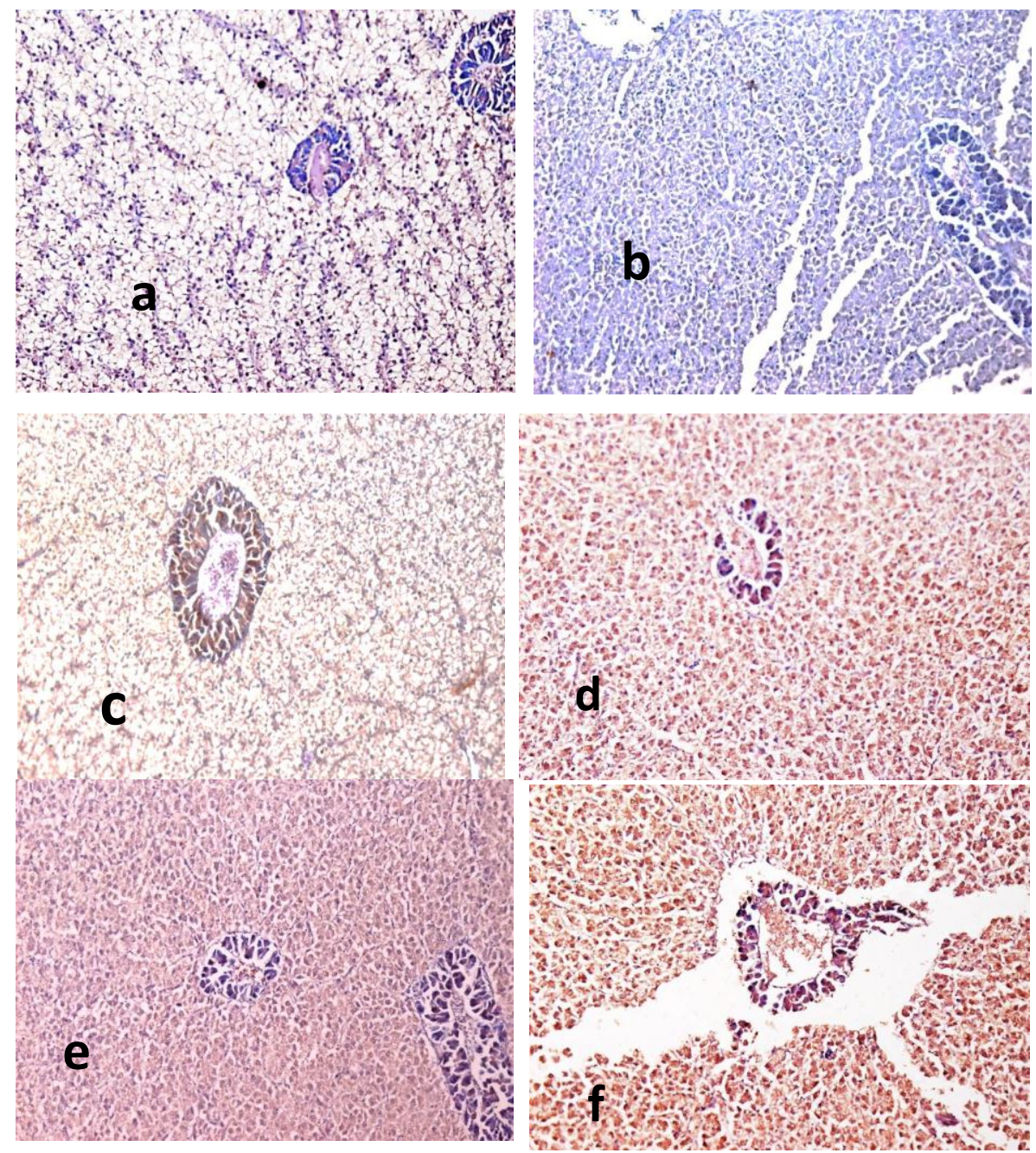

Fig (6) . Light photomicrograph for transverse sections in the liver tissues in Oreochromis niloticus fish from Manzala Lake.

a) MT negative expression in control fish liver cells (MTX200)

b) MT negative expression in liver cells and pancreatic acini in fish from Dakahlia (MTX200)

c) MT negative expression in cytoplasm of cells of liver and MT positive expression in cytoplasm of pancreatic acini cells in fish from Port Said (MT X200)

d) MT positive expression in cytoplasm of cells of liver and pancreatic acini in fish from Damietta (MT X200)

e) MT positive expression in cytoplasm of pancreatic acini cells in fish from Port Said (MT $\mathrm{X} 100)$

f) MT positive expression in cytoplasm of liver cells and pancreatic acini cells in fish from Port Said (MT X200) 


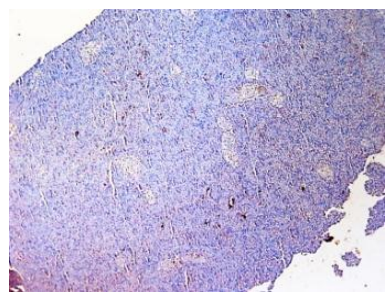

a

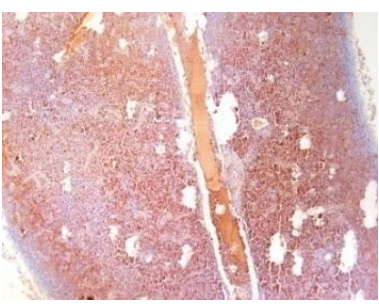

b

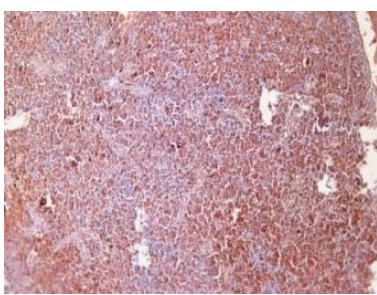

d

Fig (7). Light photomicrograph for transverse sections in the spleen of Oreochromis niloticus fish from Manzala Lake

a) MT negative expression in control fish spleen (MTX50)

b) MT positive expression in scattered cells of spleen from Damietta (MTX50)

c) MT positive expression in scattered cells of spleen from Dakahlia (MTX100)

d) MT positive expression in scattered cells of spleen from Port Said (MTX100)

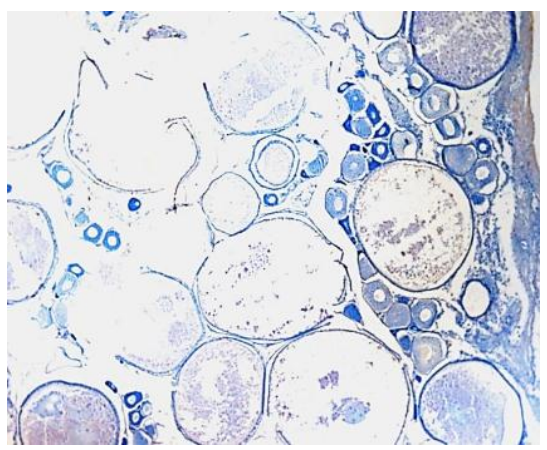

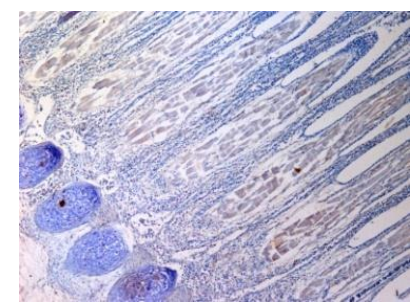

a

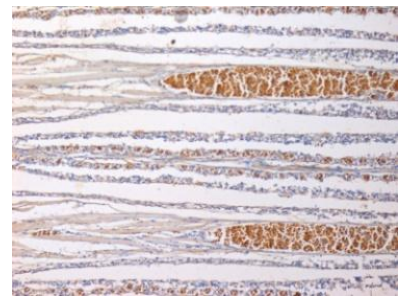

b
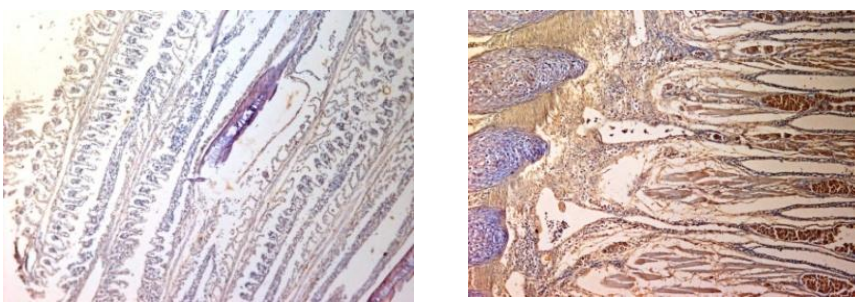

C

Fig (8). Light photomicrograph for transverse sections in gills of Oreochromis niloticus fish from Manzala Lake.

a) Negative MT in Fish Gills in fish from Damietta (MT X100)

b) MT positivity in scattered cells in filaments in fish from Damietta (MTX200)

c) MT positivity in filaments of pillar system in fish from Dakahlia (MT X100)

d) MT positivity in filaments in fish from Port Said (MT X100)

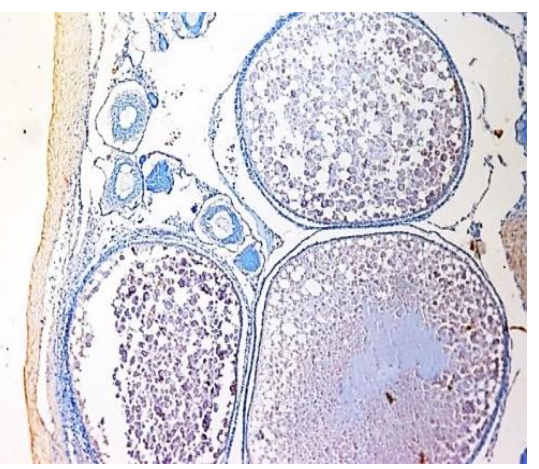

Fig (9). Light photomicrograph for transverse sections in ovary of Oreochromis niloticus fish from Manzala Lake.

a) MT negative expression in Yolk of ova, mature oocytes in fish from Port Said (MTX50)

b) MT positive expression in ovarian membrane and cytoplasm of premature ova in fish from Dakahlia (MT X100). 


\section{DISCUSSION}

Metallothionein was used by many investigators as a biomarker for assessment of heavy metal stress in the field of applied biosciences for environmental pollution in snails (Ravera,1977 and Allah et al., 1997), fish (Rosesijadi, 1996 and Wu et al., 2000), Calonectris diomedea (Stewart et al.,1996), Major Carp Species (Singha et al., 2011). The present work used $B$. alexandrina snails and $O$. niloticus fish as bioindicators through determining their MT immunopositivity tissue expression as an evidence for presence of the heavy metals $\mathrm{Cd}, \mathrm{Cu} \& \mathrm{~Pb}$ in Lake Manzala. The Lake sites in Port Said and Damietta governorates showed significantly increased heavy metal levels compared to Dakahlia and were over the concern levels of USEPA , 2011. Alonso et al. (2005) reported that heavy metals play a crucial role in various biological functioning of aquatic organisms; the severity of metal toxicity is different between species because it depends on what kinds of metal and the species dexterity to synthesize metallothionein naturally in their system. El-Khayat et al. (2018) used the same aquatic organisms; B. alexandrina snails and $O$. niloticus fish, as bio-indicators for the presence of pollutants in Lake Burullus nearby waste water discharge areas and recorded that water quality adversely affect their physiological and hematological parameters. The present results detected immunopositivity in different examined parts of snails; head foot, prostate tubules, stomach, digestive gland and ovotestis and fish organs; liver, spleen, gills \& ovary. Positive correlation was confirmed between higher levels of $\mathrm{Cu}, \mathrm{Pb} \& \mathrm{Cd}$ recorded in Port Said and Damietta sites and the pronounced MT immuno-reactivity in their samples of both B. alexandrina and $O$. niloticus compared to those from Dakahlia, indicating that the increased level of MT was parallel to the increased pollution levels of these metals. These findings consistent with Dallinger et al.(2004) who found that there is a strong correlation between heavy metals, particularly $\mathrm{Cd}$ accumulation, and MT concentration. As well, Pedrini-Martha et al. (2016) reported that, MT genes can be up regulated in response to exposure to the corresponding metal ion. In addition, Roch et al. (1982), Olsson and Haux (1986), Sulaiman et al. (1991) and Hylland et al. (1992) evidenced that an elevated level of MT in fish indicates that the fish has been exposed to heavy metals $\mathrm{Pb}, \mathrm{Cu}$ and $\mathrm{Cd}$. Furthermore, Stewart et al. (1996) reported positive correlation between MT expression and $\mathrm{Cd} \& \mathrm{Cu}$ accumulation in kidney and liver of black-backed gulls.

The data of snails and fish samples showed MT immunopositivity. Regarding the number of MT-positive cases and number of positive cells, the immunopositivity was arranged in snails as: digestive gland $>$ prostate tubules $>$ ovotestis $>$ head-foot area. The pattern for MT expression for fish organs was: liver \& spleen> gills> ovary. These findings were also observed by Wu et al. (2006) and Çoğun et al.(2003)who stated that liver is the most common organ that principally responsible for accumulation of environmental xenobiotics in order to metabolize them. The present data showed a high MT expression in tissues of fish from liver, pancreatic acini and spleen in $O$. niloticus fish from Damietta and Port Said. Also, Metallothionein positivity was significantly more expressed in the filamental epithelium of gills in $O$. niloticus fish specimens from Port Said and Damietta compared to Dakahlia, and it is known that the toxic impact of metals is primarily as a result of accumulation in the tissues of fish gills which lead to their damage. Similarly, Dang et al. (1999) found more MT positivity in gills of $O$. niloticus fish. In ovary tissues, half of $O$. niloticus fish from Damietta and Dakahlia were positive for Metallothionein compared to quarter of fish from Port Said. 
Ghedira et al. (2010) found that MT induction following intraperitoneal injection of cadmium. In addition, Ahmad et al. (2000) reported that induction of MT biosynthesis after exposure to $\mathrm{Cu}$. Furthermore several studies described MTs to play a major role in the detoxification of $\mathrm{Cd}$, and this process is clearly organ-specific (De Smetet al., 2001) and also MTs play a role in the oxidative defense against chronic copper exposure in the liver of a fresh water catfish Channa punctatus. These findings match our results that indicate expression of MT correlates with increased heavy metals especially $\mathrm{Cu}$ that the most high metal over the concern level of USEPA,2011 followed by $\mathrm{Cd}$.

\section{CONCLUSION}

positive correlation was proved between heavy metal levels $(\mathrm{Cd}, \mathrm{Cu}$ and $\mathrm{Pb})$ in Lake Manzala and MT expression in snails and fish from Port-Said and Damietta governorates compared to those from Dakahlia. Therefore, there is a need to periodic monitor of the aquatic environment to avoid contamination and its impacts on human health and ecosystem. MTs can play a role as a potential biomarker for toxicological studies and for assessment of heavy metal stress in aquatic environment.

\section{REFERENCES}

Ahmad, I. ; Hamid, T. ; Fatima, M.; Chand, H.S.; Jain, S.K.;Athar, M. and Raisuddin, S. (2000). Induction of hepatic antioxidants in fresh water catfish (Channa punctatus Bloch) is a biomarker of paper mill effluent exposure. Biochimica et Biophysica Acta ., 1523: 37-48.

Allah, A.T.; Wanas, M.W.S.and Thompson, S.N. (1997). Effects of heavy metals on survival and growth of Biomphalaria glabrata Say (Gastopoda: Pulmonata) and interaction with schistosome infection. J. Molluscan Stud., 63:79-86.

Alonso, M. L.; Prieto, F.; Miranda, M. and Castillo, C. (2005) . The role of metallothionein and zinc in hepatic copper accumulation in cattle. The Veterinary Journal, 169: 262-267.

Atli, G. and Canli, M.( 2007) . Enzymatic responses to metal exposures in a fresh water fish Oreochromis niloticus. Comparative Biochemistry and Physiology Part C. Toxicology \& Pharmacology, 15(2): 282-287.

Çoğun, H. Y.; Yüzereroğlu, T. A. and Kargin, F. (2003) . Accumulation of copper and cadmium in small and large Nile tilapia Orecochromic niloticus. Bulletin of Environment Contamination Toxicology, 71: 1265-1271.

Dallinger, R.; Chabicovsky, M.; Lagg, B.; Schipflinger, R. ; Weirich, H.G. and Berger, B.(2004) . Isoform-specific quantification of metallothionein in the terrestrial gastropod Helix pomatia. A differential biomarker approach under laboratory and field conditions. Environ. Toxicol. Chem., 23(4): 902-10.

Dang, Z.; Robert, A. C.; Lock, G. F.; Sjoerd, E. and Wendelaar, B.(1999) . Metallothionein response in gills of Oreochromis mossambicus exposed to copper in freshwater. The American Physiological Society, 277: 320-33

De Smet, H. ; De Wachter, B. ; Lobinski, R. and Blust, B. (2001). Dynamics of (Cd, $\mathrm{Zn}$ )-metallothioneins in gills, liver and kidney of common carp Cyprinus carpio during cadmium exposure. Aquatic Toxicology, 52: 269-281. 
El-Khayat, H. M. M.; Abd-Elkawy, S.; Abou- ouf, N.A.; Ahmed, M .A. and Mohammed W.A. (2018). Biochemical and histological assessment of some heavy metals on Biomphalaria alexandrina snails and Oreochromis niloticus fish in Lake Burullus, Egypt. Egyptian Journal of Aquatic Biology \& Fisheries, 22 (3): 159- 182.

El-Khayat, H.M.M.; Mahmoud, K.M.A.; Gaber, H.S.; Abdel-Hamid, H.A.; and Abu Taleb, H.M.A. (2015 b) .Studies on the effect of pollution on Lake Manzala ecosystem in Port-Said, Damietta and Dakahlia Governorates Egypt. J. Egypt. Soc. Parasitol., 45 (1): 155-168.

EPA, (2011). (United States Environmental Protection Agency) National Recommended Water Quality Criteria. http://water.epa.gov/scitech/swguidance/standards/ criteria/ current/index.

Freisinger, E .and Vašák, M. (2013)."Cadmium in metallothioneins". Metal Ions in Life Sciences, 11: 339-71.

Ghedira, J.; Jebali, J.; Bouraoui, Z.; Banni, M. ; Guerbej, H. and Bousetta, H. (2010). Metallothionein and metal levels in liver, gills and kidney of Sparus aurata exposed to sublethal doses of cadmium and copper. Fish Physiology and Biochemistry, 36:101-107.

Haram Hassan AbassBakhiet, (2015). Determination of Heavy Metals in fish tissues and water from White Nile Khartoum City-Sudan. Journal of Environment Protection and sustainable Development, 1(3): 178-181.

Herawati, N.; Suzuki, S.; Hayashi, K. ; Rivai, I .F. and Koyoma, H. (2000). Cadmium, copper and zinc levels in rice and soil of Japan,Indonesia and China by soil type. Bulletin of Environmental Contamination and Toxicology, 64:33-39

Hylland, K.; Haux, C. and Hogstrand, C. (1992). Hepatic metallothionein and heavy metals in dab Limandalimanda from the German Bright. Marine Ecology Progress Series, 91: 89-96.

Ibrahim, A.; Bahnasawy, M.; Mansy, S.and El-Fayomy, R. (1999). Distribution of heavy metals in the Damietta Nile Estuary ecosystem. Egypt. J. Aquat. Biol. Fish. 3:369397.

Jobin, W.R. (1970). Population dynamics of aquatic snails in three farm ponds in Puerto Rico. Amer. J. Trop. Med. Hyg. 19:1038-48.

Ladhar-Chaabouni, R. and Machreki Chaffai, A. (2012). Use of metallothioneins as biomarkers for environmental quality assessment in the Gulf of Gabes (Tunisia). Environmental Monitoring and assessment, 184(4): 2177-2192.

Li, J. S.; Li, J. L. and Wu, T. T. (2007). The effects of copper, iron and zinc on digestive enzyme activity in the hybrid tilapia O. niloticus (L.) x Oreochromis aureus (Steindachner). Journal of Fish Biology, 71: 1788-1798.

M'kandawire, E. ; Syakalima, M. ; Muzandu, K. ; Pandey, G. ; Simuunza, M. ; Nakayama, S. M. M. and Ishizuka, M. (2012). The nucleotide sequence of metallothioneins (MT) in liver of the Kafue lechwe (Kobus leche kafuensis) and their potential as biomarkers of heavy metal pollution of the Kafue River. Gene, 506, 310-316.

McClelland, W.J. (1965). The production of cercariae by Schistosoma mansoni and Schistosoma haematobium and methods for estimating the numbers of cercariae in suspension. Bull. World Health Orga. 3: 270-276. 
Mohamed, F.A.S. (2009). Histopathological studies on Tilapia zilli and Solea vulgaris from lake Quran, Egypt. World J. Fish Marine Sci. 23(4):1:29

Olsson, P.E. and Haux, C. (1986). Increased hepatic metallothionein content correlates to cadmium accumulation in environmentally exposed perch (Perca fluviatilis). Aquatic Toxicology, 9: 231-242.

Pedrini-Martha, V.; Niederwanger, M.; Kopp, R.; Schnegg, R.and Dallinger, R. (2016). Physiological, diurnal and stress-related variability of cadmium-metallothionein gene expression in land snails. PLos One, 11(3): 1-19

Ravera, O. (1977) .Effects of heavy metals (cadmium, copper, chromium and lead) on a freshwater snail Biomphalaria glabrataSay (Gastropoda, Prosobranchia). Malacologia,16: 231-236.

Roch, M.; Mccarter, J.A.; Matheson, A.T.; Clark, M.J.R. and Olafson, R.W.(1982) . Hepatic metallothionein in rainbow trout (Salmo gairdneri) as an indicator of metal pollution in the Campbell River system. Canadian Journal of Fisheries and Aquatic Sciences, 39: 1596-1601.

Roesijadi, G. (1996) .Metallothionein and its role in toxic metal regulation. Comparative Biochemical and Physiology, 11(2) .117-123.

Singha, R. U.; Chattopadhyay, B.; Datta, S. and Mukhopadhyay, S. K. (2011). Metallothionein as a Biomarker to Assess the Effects of Pollution on Indian Major Carp Species from Wastewater-Fed Fishponds of East Calcutta Wetlands (a Ramsar Site) .Environmental Research, Engineering and Management,4(58): 10-17.

Stern, B.R. (2010). Essentiality and toxicity in copper health risk assessment: overview, update and regulatory considerations. Toxicol Environ Health A. 73(2):114-127

Stewart, F.M.; Furness, R.W. and Monteiro, L.R. (1996). Relationship between heavy metal and metallothionein concentrations in lesser black-backed gulls, Larus fuscus, and Cory's shearwater, Calonectris diomedea. Archives of Toxicology, 30: 299305.

Sulaiman, N.; George, S. and Burke, M.D. (1991). Assessment of sublethal pollutant impact on flounders in an industrialized estuary using hepatic biochemical inducers. Marine Ecology Progress Series, 68: 207-212.

Sutton, D.J.and Tchounwou, P.B. (2007). Mercury induces the externalization of phosphatidylserine in human proximal tubule (HK-2) cells. Intl. J. Environ. Res .Public Health. 4(2):138-144.

Tchounwou, P.B. ;Centeno, J.A. and Patlolla, A.K.(2004). Arsenic toxicity, mutagenesis and carcinogenesis a health risk assessment and management approach. Mol Cell Biochem., 255:47-55.

Wegwu, M. O.; Ibeh, G. O.and Abber, B. W. (2010). Evaluation of toxicity of varied concentrations of mercury and copper on Oreochromis niloticus. Scientia Africana, 9(1): 86-92.

Wong, Daisy. L. Merrifield-MacRae, Maureen E.; Stillma, Martin J. (2017). "Chapter 9.Lead (II) Binding in Metallothioneins". In Astrid, S.; Helmut, S.; Sigel, R. K. O. Lead: Effects on Environment and Health. Metal Ions in Life Sciences, 17. de Gruyter. pp. 241-270.

Wu, S. M.; Chen, C. C.; Lee, Y. C.; Leu, H. T. and Lin, N. S. (2006). Cortisol and copper induce metallothionein expression in three tissues of tilapia (Oreochromis mossambicus) in organ culture. Zoological Studies, 45(3): 363-370. 
Wu, S.M.; Weng, C.F.; Hwang, J.C.; Huang, C.J. and Hwang, P.P.(2000). Metallothionein induction in early stage of tilapia (Oreochromis mossambicus).Physiological and Biochemical Zoology, 73: 531-537.

Yousif, F.; Khalil, M. and El-Emam, M. (1992). Evaluation of three common tools in estimating B. alexandrina population in irrigation ditches. Egypt. J. Bilh., 14:151-8.

\section{ARABIC SUMMARY}

تقييم تعبير الميتالوثيونين في قو اقع Biomphalaria alexandrina و أسماك البلطي النيلى Oreochromis كمؤشربيولوجيي لتلوث المياه بالمعادن الثقيلة . niloticus

$$
\begin{aligned}
& \text { هناءمحمودمحمدالخياط 'ــ هديمحمد ابو طالب } 1 \text {-نهي سعيد هلال '- سماح ابراهيم غنيم' } \\
& \text { قسم بحوث البيئة و الرخويات الطبية } 1 \text { ـ قسم الباثولوجي ' ـمعهد تيودوربلهارس-جيزهـ مصر. }
\end{aligned}
$$

المينالوثيونين هي بروتينات صغيرة غنية بالسبستين تلعب أدوارًا مهمة في التوازن المعدني و الحماية من المعادن

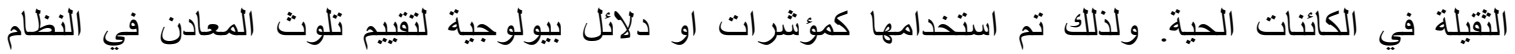

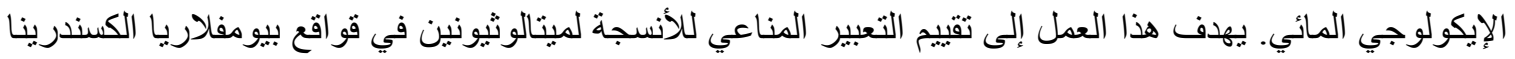

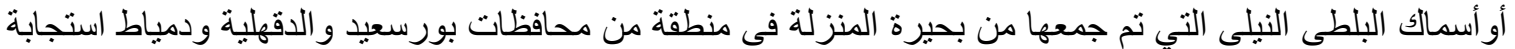

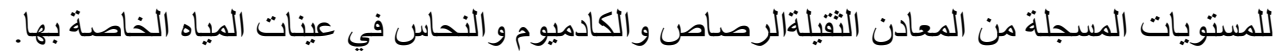

ونلاحظ أن التعبير النسيجي للمينالوثيونين قد زاد بشكل ملحوظ في القو اقع وأسماك البلطى النيلى من بورسعيد

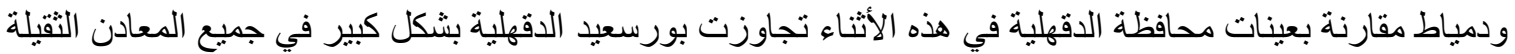

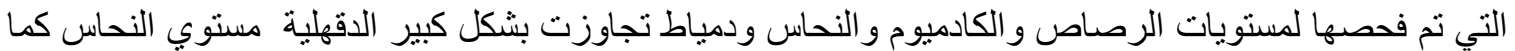

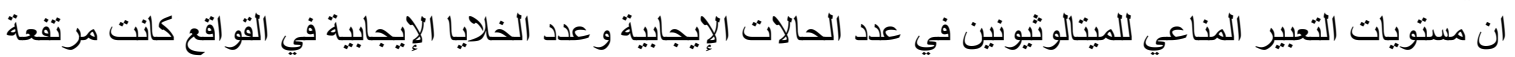

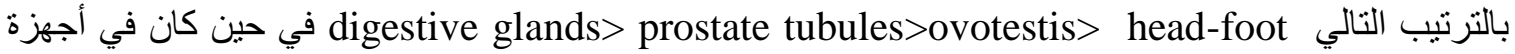

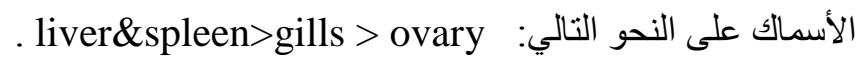

الاستنتاج : لوحظ ارتباط إيجابي بين مستوى المعادن الثقيلة والتعبير المينالوثيونين في القواقع والأسماك

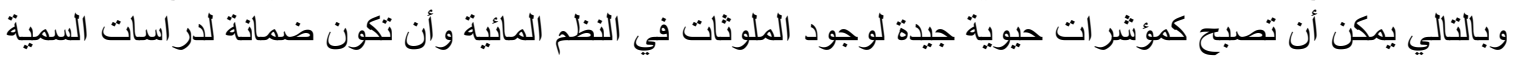
ولتقييم الإجهاد المعادن الثقيلة في البيئة المائية. 